\title{
Rapid syntheses of difluorinated dihydropyrans
}

\author{
Jonathan M. Percy* and Stéphane Pintat \\ School of Chemistry, University of Birmingham, Edgbaston, Birmingham, UK B15 2TT. \\ E-mail: jmpercy@chemistry.bham.ac.uk
}

Received (in Liverpool, UK) 4th January 2000, Accepted 15th February 2000

A very short reaction sequence opens with metal-mediated addition of commercial bromodifluoropropene to aldehydes; allylation under phase transfer catalysed conditions sets the stage for a ring closing metathesis (RCM) in the presence of commercial Grubbs' catalyst to afford potentially useful difluorinated dihydropyrans.

Difluorinated carbohydrate analogues are normally prepared by DAST [(diethylamino)sulfur trifluoride] difluorination of highly protected precursors in which a ketonic carbonyl group has been isolated, chemistry which is highly vulnerable to stereoelectronic effects as demonstrated many times by Castillón and coworkers. ${ }^{1}$ Even when such difficulties have been overcome, the hazardous nature of the DAST reagent precludes scale-up, while safer versions of the reagent sacrifice reactivity in the cause of thermal stability. ${ }^{2}$ Building block chemistry then appears most attractive and the Reformatsky reaction of ethyl bromodifluoroacetate with aldehydes and other electrophiles is a well-worked and productive theme. ${ }^{3}$ Our own approaches have relied on metallated difluoroenol derivatives fashioned in situ from trifluoroethanol but we were struck by the simplicity of a possible RCM-based approach. ${ }^{4}$ Scheme 1 shows the analysis; the route closely follows that published recently by Carda et al. ${ }^{5}$ but forms the first instance where RCM technology has been used for the synthesis of ring-fluorinated heterocycles.

Initially, we were interested in the reproducibility of the allylindium chemistry described by Momose and coworkers 6 in which bromodifluoropropene adds very smoothly to aldehydes. With the homoallyl alcohols in hand, we would perform an allylation and then expose the allyl homoallyl ether to an RCM catalyst. Both alkenes are made less electron rich by electronwithdrawing substitutents at the allyl position and we were concerned that the overall cycle would be slow and that metallo$[2+2]$ cycloaddition in the fluorinated allyl system could result in $\beta$-fluoride elimination with concomitant formation of a strong metal-fluorine bond destroying the catalyst.

In the event, our fears were groundless. The allylindium chemistry was highly reproducible and homoallyl alcohols $\mathbf{2 a -}$ d were synthesised in moderate to high (57-80\%) yield (Scheme 2).

The reactions worked best when the suspensions were shaken or sonicated, and purification was facile. ${ }^{7}$ We also explored the replacement of the indium metal with 325-mesh zinc under the

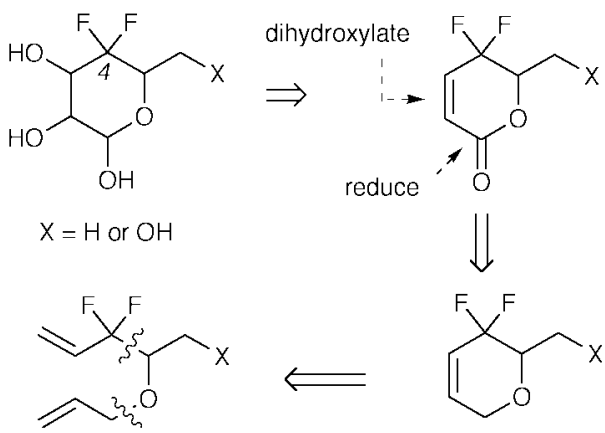

Scheme 1

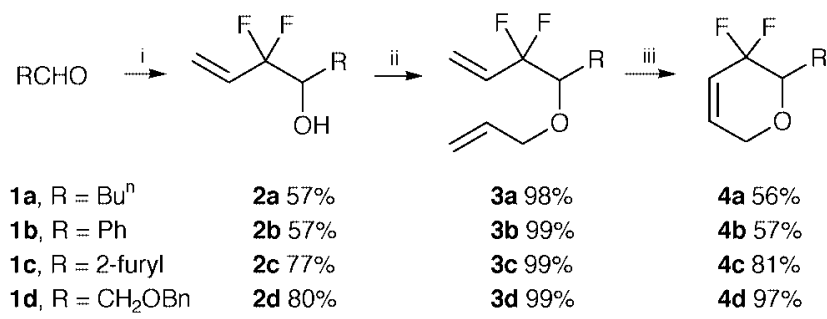

Scheme 2 Reagents and conditions: $\mathrm{i}, \mathrm{H}_{2} \mathrm{C}=\mathrm{CHCF}_{2} \mathrm{Br}$, In, DMF, sonication, room temp.; ii, $\mathrm{H}_{2} \mathrm{C}=\mathrm{CHCH}_{2} \mathrm{Br}, \mathrm{NaOH}, \mathrm{CH}_{2} \mathrm{Cl}_{2}, \mathrm{Bu}_{4} \mathrm{NHSO}_{4}$, room temp.; iii, $5 \mathrm{~mol} \%$ Grubbs' catalyst, $\mathrm{CH}_{2} \mathrm{Cl}_{2}$, rt, $24 \mathrm{~h}$.

conditions described by Wilson and Guazzaroni (saturated $\left.\mathrm{NH}_{4} \mathrm{Cl}, \mathrm{THF}\right) .{ }^{8}$ The zinc-mediated reaction ${ }^{9}$ was much more effective in the case of benzaldehyde, affording the homoallyl alcohol $\mathbf{2 b}$ in $84 \%$ yield, but less effective (37\%) when the more interesting and electrophilic benzyloxyacetaldehyde 1d was present, despite our observation of an extremely clean ${ }^{19} \mathrm{~F}$ NMR spectrum from the crude material. Pinacol coupling of the aldehyde may be responsible for the low yield though we did not isolate any products of this type.

Allylation ${ }^{10}$ was trouble-free as was the RCM reaction ${ }^{11}$ at room temperature in dichloromethane, though reaction times of $24 \mathrm{~h}$ were required to consume the starting material entirely.<smiles>C=CC(C)(C)OC(COCCCC)C(F)(F)C=C</smiles>

The methallyl ether 5 prepared by an analogous sequence failed to cyclise at all under these conditions suggesting that the additional steric hindrance imposed by a methyl group is enough to prevent coordination and stop the cycle. Dihydropyran $\mathbf{4 d}$, formed in a particularly high isolated and purified yield is of the type identified in the analysis, while $\mathbf{4 c}$ is potentially interesting for the synthesis of higher sugars and related species; we are continuing to explore the scope of the reaction more fully. This short study clearly shows how potentially important oxygen heterocycles can be assembled in an extremely concise manner using off-the-shelf reagents.

We wish to thank the EPSRC (GR/K84882) and the University of Birmingham for financial support and Dr Philip Walker (Fluorochem Ltd.) for a generous gift of 1-bromo1,1-difluoropropene.

\section{Notes and references}

1 M. I. Barrena, M. I. Matheu and S. Castillón, J. Org. Chem., 1998, 63 2184; R. Fernández and S. Castillón, Tetrahedron, 1999, 55, 8497.

2 G. S. Lal, G. P. Pez, R. J. Pesaresi, F. M. Prozonic and H. Cheng, J. Org. Chem., 1999, 64, 7048.

3 For a full discussion of two-carbon fluorinated building blocks, see: J. M. Percy, Top. Curr. Chem., 1997, 193, 131.

4 R. H. Grubbs and S. Chang, Tetrahedron, 1998, 54, 4413. For a recent and most attractive approach to cyclitols, see: L. Hyldtoft, C. S. Poulsen and R. Madsen, Chem. Commun., 1999, 2101. 
5 M. Carda, E. Castillo, S. Rodríguez, S. Uriel and J. A. Marco, Synlett, 1999, 1639.

6 M. Kirihara, T. Takuwa, S. Takizawa and T. Momose, Tetrahedron Lett., 1997, 38, 2853.

7 Preparation: of 2d: 1-bromo-1,1-difluoropropene (0.76 ml, $7.5 \mathrm{mmol})$ and benzyloxyacetaldehyde $(0.70 \mathrm{ml}, 5.0 \mathrm{mmol})$ were added to a sonicated suspension of indium powder $(0.86 \mathrm{mg})$ in DMF $(20 \mathrm{ml})$. The mixture was sonicated at room temperature for $5 \mathrm{~h}$ then quenched with $1 \mathrm{M} \mathrm{HCl}(10 \mathrm{ml})$. Extractive work up afforded a yellow oil which was purified by column chromatography [30\% diethyl ether-light petroleum (bp $\left.40-60{ }^{\circ} \mathrm{C}\right)$ ] to afford $2 \mathrm{~d}$ as a pale yellow oil $(0.91 \mathrm{~g}, 80 \%)\left(R_{\mathrm{f}}=\right.$ $0.23) .{ }^{1} \mathrm{H} \mathrm{NMR}\left(\mathrm{CDCl}_{3}, 300 \mathrm{MHz}\right) \delta 7.40-7.28(\mathrm{~m}, 5 \mathrm{H}), 6.09-5.81(\mathrm{~m}$, $1 \mathrm{H}), 5.72\left(\mathrm{dt}, 1 \mathrm{H},{ }^{3} J_{\mathrm{H}-\mathrm{H}} \quad 17.5,{ }^{4} J_{\mathrm{H}-\mathrm{F}} 2.6 \mathrm{~Hz}\right), 5.52\left(\mathrm{~d}, 1 \mathrm{H},{ }^{3} J_{\mathrm{H}-\mathrm{H}} 11.0\right.$ $\mathrm{Hz}), 4.6(\mathrm{~s}, 2 \mathrm{H}), 4.10-3.98(\mathrm{~m}, 1 \mathrm{H}), 3.71(\mathrm{dd}, 1 \mathrm{H}$, first half of an $\mathrm{AB}$ quartet, $\left.{ }^{2} J_{\mathrm{H}-\mathrm{H}}=9.9,{ }^{3} J_{\mathrm{H}-\mathrm{H}} 3.3 \mathrm{~Hz}\right), 3.59(\mathrm{dd}, 1 \mathrm{H}$, second half of an $\mathrm{AB}$ quartet, $\left.{ }^{2} J_{\mathrm{H}-\mathrm{H}} 9.9,{ }^{3} J_{\mathrm{H}-\mathrm{H}} 7.0 \mathrm{~Hz}\right), 2.76\left(\mathrm{~d}, 1 \mathrm{H},{ }^{3} J_{\mathrm{H}-\mathrm{H}} 5.2 \mathrm{~Hz}\right) ;{ }^{13} \mathrm{C} \mathrm{NMR}$ $\left(\mathrm{CDCl}_{3}, 75 \mathrm{MHz}\right) \delta 137.3,129.9\left(\mathrm{t},{ }^{2} J_{\mathrm{C}-\mathrm{F}} 25.5 \mathrm{~Hz}\right), 128.4,127.9,127.7$, $120.9\left(\mathrm{t},{ }^{3} J_{\mathrm{C}-\mathrm{F}} 9.5 \mathrm{~Hz}\right), 119.1\left(\mathrm{t},{ }^{1} J_{\mathrm{C}-\mathrm{F}} 273.7 \mathrm{~Hz}\right), 73.6,72.2\left(\mathrm{t},{ }^{2} J_{\mathrm{C}-\mathrm{F}}\right.$ $33.6 \mathrm{~Hz}), 68.6 ;{ }^{19} \mathrm{~F} \mathrm{NMR}\left(\mathrm{CDCl}_{3}, 282 \mathrm{MHz}\right) \delta-107.3$ (dt, $1 \mathrm{~F}$, first half of an $\mathrm{AB}$ quartet, $\left.{ }^{2} J_{\mathrm{F}-\mathrm{F}} 251.8,{ }^{3} J_{\mathrm{F}-\mathrm{H}} 10.5 \mathrm{~Hz}\right),-111.3(\mathrm{dt}, 1 \mathrm{~F}$, second half of an AB quartet, $\left.{ }^{2} J_{\mathrm{F}-\mathrm{F}} 251.8,{ }^{3} J_{\mathrm{F}-\mathrm{H}} 11.1 \mathrm{~Hz}\right) ; \mathrm{m} / \mathrm{z}$ (ES) $251(\mathrm{M}+$ $\mathrm{Na}, 100$ ); HRMS calc. for $\mathrm{C}_{12} \mathrm{H}_{14} \mathrm{O}_{2} \mathrm{~F}_{2} \mathrm{Na} 251.0860$, found 251.0872 . 8 S. R. Wilson and M. E. Guazzaroni, J. Org. Chem., 1989, 54, 3087.

9 For other difluoroallylation methods or building blocks, see: Z-Y. Yang and D. J. Burton, J. Org. Chem., 1991, 56, 1037; J. Gonzalez, M. J. Foti and S. Elsheimer, Org. Synth., 1995, 72, 225; M. Fujita, M. Obayashi and T. Hiyama, Tetrahedron, 1988, 44, 4135

10 M. Schlosser and S. Strunk, Tetrahedron, 1989, 45, 2649.

11 Preparation of 4d: a mixture of allyl homoallyl ether $\mathbf{3 d}$ (403 mg, 1.5 $\mathrm{mmol}$ ) and Grubbs' catalyst $(62 \mathrm{mg}, 5 \mathrm{~mol} \%)$ in dry degassed DCM was stirred for $24 \mathrm{~h}$ under an atmosphere of nitrogen. The mixture was concentrated in vacuo to give a black oil. Purification by column chromatography using 5\% diethyl ether-light petroleum ether (bp $\left.40-60{ }^{\circ} \mathrm{C}\right)$ as eluent, afforded $\mathbf{4 d}$ as a pale yellow oil $(350 \mathrm{mg}, 97 \%)\left(R_{\mathrm{f}}\right.$ $=0.30){ }^{1} \mathrm{H} \mathrm{NMR}\left(\mathrm{CDCl}_{3}, 300 \mathrm{MHz}\right) \delta 7.33-7.27(\mathrm{~m}, 5 \mathrm{H}), 6.30-6.24$ $(\mathrm{m}, 1 \mathrm{H}), 5.95-5.86(\mathrm{~m}, 1 \mathrm{H}), 4.67(\mathrm{~d}, 1 \mathrm{H}$, first half of an $\mathrm{AB}$ quartet, $\left.{ }^{2} J_{\mathrm{H}-\mathrm{H}} 12.1 \mathrm{~Hz}\right), 4.59\left(\mathrm{~d}, 1 \mathrm{H}\right.$, second half of an AB quartet, ${ }^{2} J_{\mathrm{H}-\mathrm{H}} 12.1$ $\mathrm{Hz}), 4.37,4.18(\mathrm{~m}, 2 \mathrm{H}), 3.98-3.94(\mathrm{~m}, 1 \mathrm{H}), 3.90(\mathrm{dd}, 1 \mathrm{H}$, first half of an AB quartet, $\left.{ }^{2} J_{\mathrm{H}-\mathrm{H}} 10.8,{ }^{3} J_{\mathrm{H}-\mathrm{H}} 2.4 \mathrm{~Hz}\right), 3.71(\mathrm{dd}, 1 \mathrm{H}$, second half of an $\mathrm{AB}$ quartet, $\left.{ }^{2} J_{\mathrm{H}-\mathrm{H}} 10.8,{ }^{3} J_{\mathrm{H}-\mathrm{H}} 7.9 \mathrm{~Hz}\right) ;{ }^{13} \mathrm{C} \mathrm{NMR}\left(\mathrm{CDCl}_{3}, 75 \mathrm{MHz}\right) \delta$ $137.8,135.7\left(\mathrm{t},{ }^{3} J_{\mathrm{C}-\mathrm{F}} 9.0 \mathrm{~Hz}\right), 128.5,127.9,121.4\left(\mathrm{t},{ }^{2} J_{\mathrm{C}-\mathrm{F}} 28.0 \mathrm{~Hz}\right)$, $113.9\left(\mathrm{dd},{ }^{1} J_{\mathrm{C}-\mathrm{F}} 243.0,235.7 \mathrm{~Hz}\right), 77.0\left(\mathrm{~d},{ }^{2} J_{\mathrm{C}-\mathrm{F}}, 30.5 \mathrm{~Hz}\right), 73.8,67.1(\mathrm{~d}$, $\left.{ }^{3} J_{\mathrm{C}-\mathrm{F}}, 5.7 \mathrm{~Hz}\right), 65.2 ;{ }^{19} \mathrm{~F} \mathrm{NMR}\left(\mathrm{CDCl}_{3}, 282 \mathrm{MHz}\right) \delta-105.6$ (ddt, $1 \mathrm{~F}$, first half of an $\mathrm{AB}$ quartet, $\left.{ }^{2} J_{\mathrm{F}-\mathrm{F}} 274.0,{ }^{3} J_{\mathrm{F}-\mathrm{H}} 17.8,8.9,{ }^{4} J_{\mathrm{F}-\mathrm{H}}=8.9 \mathrm{~Hz}\right)$, -107.7 (br d, ${ }^{2} J_{\mathrm{F}-\mathrm{F}} 274.0,{ }^{3} J_{\mathrm{F}-\mathrm{H}} 4.4 \mathrm{~Hz}$ ); $\mathrm{m} / z$ (ES) $263(\mathrm{M}+\mathrm{Na}, 100)$; HRMS calc. for $\mathrm{C}_{13} \mathrm{H}_{14} \mathrm{O}_{2} \mathrm{~F}_{2} \mathrm{Na} 263.0860$, found 263.0853 . 